\title{
Households' climate change adaptive capacity in the Lake Victoria Basin, Kenya
}

\author{
${ }^{1}$ Omemo Peter, ${ }^{2}$ Olago Daniel, ${ }^{2}$ Ogara William, ${ }^{2}$ Wandiga Shem \\ ${ }^{I}$ Department of Public Health, School of Health sciences, Jaramogi Oginga Odinga University of Science and \\ Technology, P.O Box 280, Bondo, Kenya. \\ ${ }^{2}$ Institute for Climate Change and Adaptation, University of Nairobi, P.O Box 30197-00100, Nairobi, Kenya
}

\begin{abstract}
A households' climate change adaptive (CCA) capacity simply refers to the household head's potential to effectively respond to climate change induced forcings. The households' adaptive capacity hinges on several factors. This paper reports the evaluation results of the households' CCA capacity in the Lake Victoria Basin (LVB), Kenya. The knowledge, attitude and practices (KAP) of households are said to be predictors of households' CCA capacity. There is evidence that over the past 30 years, a number of permanent streams in the LVB, Kenya, have dried up. Across sectional survey was conducted in Gwasi and Nyando areas within the LVB, Kenya. The level of education of respondents was $44.2 \%(\mathrm{n}=523)$ primary, 35\% high school and $20.8 \%$ diploma training and above. The level of awareness of CC was $62 \%$ and $94.6 \%$ among the male respondents in Gwasi and Nyando respectively. About $57.9 \%(\mathrm{n}=523)$ stated that both human activities and natural changes are responsible for the CC. Approximately $27.2 \%(\mathrm{n}=261)$ and $33.5 \%(\mathrm{n}=262)$ in Gwasi and Nyando respectively store roof catchment water. Approximately $35.3 \%(n=261)$ and $22.2 \%(n=262)$ in Gwasi and Nyando respectively keep donkeys for water transport. These results reveals that the CCA was positively influenced by household heads' KAP
\end{abstract}

Keywords: Households, adaptive capacity, climate change and variability.

\section{INTRODUCTION}

Households' climate change adaptive capacity has been defined as the potential of the individuals to effectively respond to local climate variability and change [1]. Households' adaptive capacity processes involve formulating options and making decisions [2]. These processes are driven by several factors i.e. knowledge and information, asset base, innovation, institutions and flexible forward-looking decision-making [3].Global climate change forcings are already having dramatic effects on rural household's sources of livelihood. The consequence of climate change and variability on households is manifested in the changing rainfall patterns and droughts in certain regions and floods in others [4]. Literature review reveals that majority of climate change adaptive assessments have focused largely on assets and capitals as indicators of household's adaptation capacity. However, asset-oriented approaches typically mask the role of knowledge and information in supporting adaptive capacity [5] In the Lake Victoria Basin for example, studies show that droughts have been more severe, frequent and prolonged in the last 30 years[6].There is also evidence of dramatic fall in the level of Lake Victoria waters affecting the livelihood of the local riparian communities. Other studies also show that over the past 30 years, a number of streams in the LVB, Kenya, such as Obuso, Atoyien'go, Nyalbiego and Ombeyi which were previously permanent, have become seasonal [7].The overall objective of this study therefore, was to assess the climate change adaptive capacity of households around the LVB, Kenya. The study specifically assessed the prevailing household's knowledge, perception and practices towards climate change in the LVB, Kenya:

\section{MATERIALS AND METHODS}

This study was conducted in two regions within the LVB, Kenya, that is; Nyando Sub County in the north and Gwasi Sub County in the South (Figure 1). Nyando Sub-County has high agricultural potential but lies on flood plains. Approximately 750,000 persons reside within the Nyando Sub County [8]. Gwasi sub-county on the other hand suffers from frequent drought although the region is very popular with local livestock husbandry. 


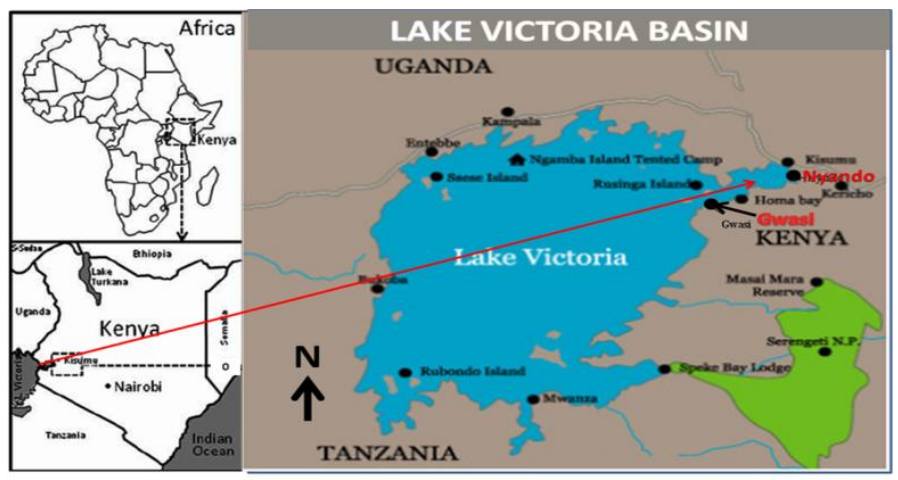

Figure 1: Map showing the study sites in the Lake Victoria basin, Kenya.

\section{Study design and data collection tools}

A cross-sectional study was conducted in Gwasi and Nyando sub counties within The LVB, Kenya. Both quantitative and qualitative techniques were used to collect primary data on the knowledge, perception and practices of household's towards climate change and adaptation. A questionnaire tool containing semi-structured questions was administered on 523 randomly selected household heads in both Gwasi and Nyando. A systematic random sampling technique was applied to identify the respondents.

\section{RESULTS AND DISCUSSIONS}

A total of five hundred and twenty three questionnaires (94.3\%) were completed. There were 261 and 262 respondents in Gwasi and Nyando areas respectively. Out of the 523 household heads interviewed 393 (75.1\%) were males and $130(24.8 \%)$ were females (Table 1$)$.

Table 1. Households' survey response statistics.

\begin{tabular}{|l|l|l|l|l|l|l|}
\hline \multirow{2}{*}{ Description } & \multicolumn{3}{|c|}{ Gwasi } & \multicolumn{3}{c|}{ Nyando } \\
\cline { 2 - 8 } & Male & Female & Total & Male & Female & Total \\
\hline Household heads contacted & 209 & 55 & 264 & 188 & 76 & 264 \\
\hline Household interviews refused & 3 & 0 & 3 & 1 & 1 & 2 \\
\hline Interviews successfully completed & 206 & 55 & 261 & 187 & 75 & 262 \\
\hline $\mathrm{n}=523$ & \multicolumn{7}{|l|}{} \\
\hline
\end{tabular}

The average age of the respondents was 33.4 (range 19 - 64) years old and a standard deviation of 7.6. About $44.2 \%$ had primary level education, 35\% reached high school and certificate level training, $20.8 \%$ attained diploma education and above. Approximately $15.1 \%$ earned $<$ KSh.1, 500, 28.6\% earned between KSh.1, 5014,500, 29.0\% earned between KSh. 4,501-9,000 and 27.3\% > KSh.9, 000 as summarized in table 2 below.

Table 2. General demographic information of the respondents

\begin{tabular}{|l|c|l|l|l|l|l|l|}
\hline \multicolumn{7}{|c|}{ Gwasi } & \multicolumn{7}{c|}{ Nvando } & \multicolumn{2}{c|}{ Total } \\
\hline Demographic Variables & $\mathrm{n}$ & $\%$ & $\mathrm{n}$ & $\%$ & $\mathrm{n}$ & $\%$ \\
\hline Respondents' Gender & 206 & 78.9 & 187 & 73.4 & 393 & 75.1 \\
\hline Males & 55 & 21 & 75 & 28.6 & 130 & 24.9 \\
\hline Females & 68 & 26.0 & 89 & 40 & 157 & 30 \\
\hline Respondents' Age & 118 & 45.2 & 75 & 42.7 & 193 & 36.9 \\
\hline $19-29$ years & 75 & 28.7 & 98 & 37.4 & 173 & 33.0 \\
\hline $30-49$ years & 119 & 45.6 & 112 & 42.7 & 231 & 44.2 \\
\hline$\geq 50$ years & 94 & 36.0 & 89 & 34.0 & 183 & 35.0 \\
\hline Respondents' Educational Level & 48 & 18.4 & 61 & 23.3 & 109 & 20.8 \\
\hline$\leq$ Primary school level & \multicolumn{7}{|l|}{} \\
\hline Secondary School & Diploma training & 21.8 & 64 & 24.4 & 121 & 23.1 \\
\hline Place of residence
\end{tabular}


Households' climate change adaptive capacity in the Lake Victoria Basin, Kenya

\begin{tabular}{|l|c|l|l|l|l|l|}
\hline Village & 204 & 78.2 & 198 & 75.6 & 402 & 76.9 \\
\hline Average monthly household income \\
\hline$<1,500$ & 78 & 29.8 & 52 & 22.2 & 130 & 15.1 \\
\hline $1,501-4,500$ & 107 & 40.9 & 111 & 36.4 & 218 & 28.6 \\
\hline $4,501-9,000$ & 66 & 25.3 & 26 & 26.9 & 92 & 29.0 \\
\hline$>9,001$ & 10 & 3.8 & 73 & 14.5 & 83 & 27.3 \\
\hline Juvenile's Health Status & 69 & 26.4 & 91 & 34.8 & 160 & 30.6 \\
\hline Healthy & 101 & 38.5 & 97 & 37.0 & 198 & 37.9 \\
\hline Fair & 91 & 34.9 & 74 & 28.2 & 165 & 31.5 \\
\hline Poor
\end{tabular}

Households' general awareness towards the prevailing global climate change was assessed through a Yes or No answer. The level of awareness of global climate change was $62 \%$ (yes) and $94.6 \%$ (yes) among the male respondents in Gwasi and Nyando respectively. However, among the female respondents 53\% (yes) and $92 \%$ (yes) respondents were in Gwasi and Nyando respectively as shown in table 3 below.

Table 3. Households' knowledge with regard to the global climate change phenomenon

\begin{tabular}{|l|l|l|l|l|}
\hline Have you ever heard about the prevailing global "Climate change"? \\
\cline { 2 - 5 } & \multicolumn{3}{|c|}{ Gwasi } & \multicolumn{2}{c|}{ Nyando } \\
\cline { 2 - 5 } & Male & Female & Male & Female \\
\hline Yes & 139 & 29 & 177 & 69 \\
\hline No & 67 & 26 & 10 & 6 \\
\hline $\mathrm{n}=523$ & \multicolumn{5}{|c|}{} \\
\hline
\end{tabular}

The respondents were asked to comment whether they believe that climate change is a reality. Households in Nyando area had a high level of knowledge about the reality of global climate change phenomenon than those in Gwasi. Table 4 below shows the summary of responses to the question "Is Climate Change phenomenon a reality?"

Table 41. Households' knowledge about the reality of global climate change phenomenon

\begin{tabular}{|l|c|l|l|l|}
\hline \multirow{2}{*}{ Is Climate Change phenomenon a reality? } \\
\cline { 2 - 5 } & \multicolumn{3}{|c|}{ Gwasi } & \multicolumn{2}{c|}{ Nyando } \\
\cline { 2 - 5 } & Male & Female & Male & Female \\
\hline Yes & 177 & 41 & 180 & 60 \\
\hline No & 29 & 14 & 3 & 7 \\
\hline Don't know & 0 & 0 & 187 & 75 \\
\hline Total & 206 & 55 & \multicolumn{3}{l|}{} \\
\hline $\mathrm{n}=516$ & \multicolumn{5}{|l}{} \\
\hline
\end{tabular}

Approximately $34.4 \%$ (180) and $34.8 \%$ (182) men in Gwasi and Nyando respectively responded that they were very sure climate change was taking place in the LVB, Kenya (Table, 5). However, only 6.3\% (33) and $11.3 \%$ (59) of women in Gwasi and Nyando respectively responded that they were very sure climate change was taking place

Table 2. Households' response to climate change happening in the LVB

\begin{tabular}{|l|l|l|l|l|}
\hline How sure are you that climate change is happening in the LVB \\
\hline Response & Gwasi & Female & Male & Female \\
\cline { 2 - 5 } & Male & 33 & 182 & 59 \\
\hline Very sure & 180 & 12 & 1 & 1 \\
\hline Not sure & 19 & 10 & 4 & 15 \\
\hline Don't know & 7 & \multicolumn{3}{l}{} \\
\hline $\mathrm{n}=523$ &
\end{tabular}

Those who answered very sure to question (i) $(n=454)$ above were asked the question; what does "climate change" mean to you?; Figure 2. 


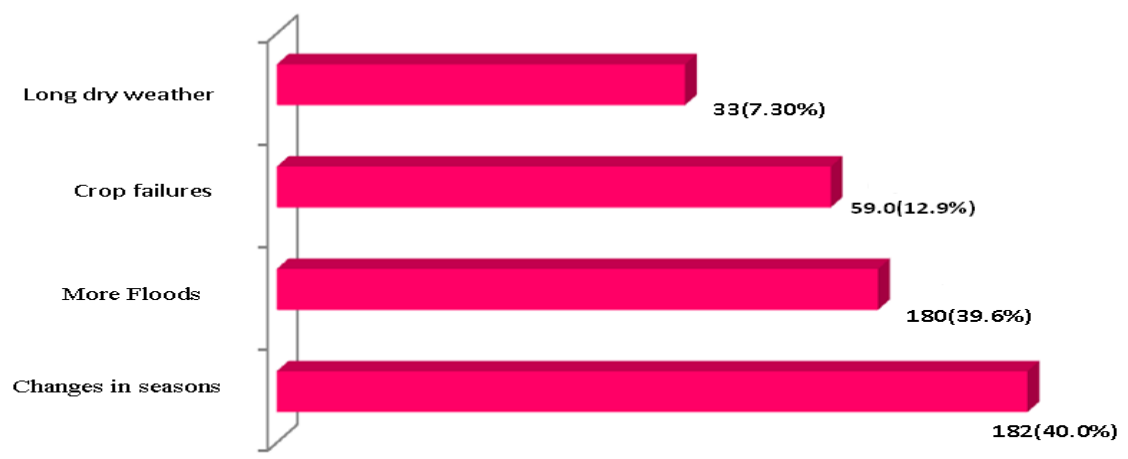

Figure 2. What climate change means to study participants?

About $39 \%(\mathrm{n}=523)$ of respondents said that climate change is caused by natural changes not human interference while $57.9 \%$ stated that both human activities and natural changes are responsible for climate change as shown in Table 6 .

Table 6. Households' knowledge about the causes of climate change

\begin{tabular}{|c|c|c|c|c|}
\hline \multirow[t]{2}{*}{ Response } & \multicolumn{2}{|c|}{ Gwasi } & \multicolumn{2}{|c|}{ Nyando } \\
\hline & Male & Female & Male & Female \\
\hline Both human activities and natural changes & 79 & 8 & 107 & 11 \\
\hline Natural changes and no human interference & 122 & 47 & 70 & 64 \\
\hline Don't know & 5 & 0 & 10 & 0 \\
\hline Total & 206 & 55 & 187 & 75 \\
\hline
\end{tabular}

The prevailing households' perception towards climate change in the LVB was assessed through a set of questions as shown below:

Table 7: In your opinion, do you think there have been changes overtime in the pattern of droughts and rain seasons in the LVB?

\begin{tabular}{|c|c|c|c|c|}
\hline \multirow[t]{2}{*}{ Response } & \multicolumn{2}{|r|}{ Gwasi } & \multicolumn{2}{|c|}{ Nyando } \\
\hline & Male & Female & Male & Female \\
\hline Yes & 204 & 55 & 177 & 66 \\
\hline No & 0 & 0 & 0 & 0 \\
\hline Don't know & 2 & 0 & 10 & 9 \\
\hline Total & 206 & 55 & 187 & 75 \\
\hline
\end{tabular}

The household responses to the question whether there have been changes overtime in the pattern of droughts and rain seasons in the LVB were in agreement with meteorological data for the LVB, Kenya obtained from the Department of Meteorological Research Station, Kisumu (Figures 3 \& 4). To understand the climate variation in the LVB, Kenya, monthly mean historical rainfall and temperature data were analysed to show the baseline climate and temperature seasonality by month, for the periods between $1960-1990$ and the periods $1990-$ 2012. 


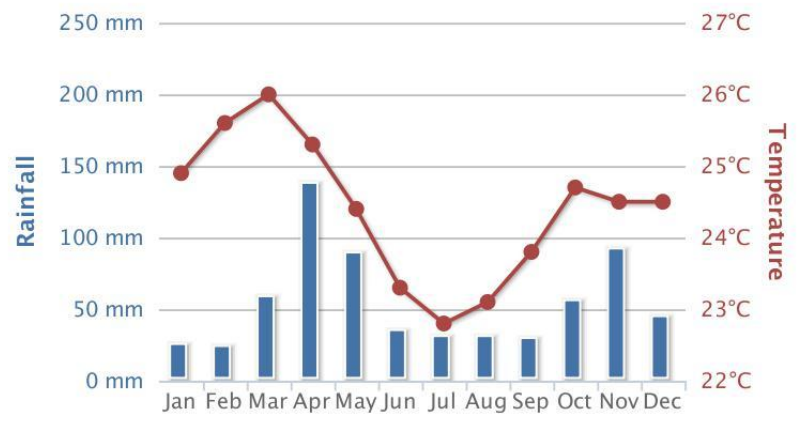

Figure 3: The 1960 - 1990 baseline climate and seasonality trend for LVB, Kenya (Data source: Meteorological department, Kisumu.

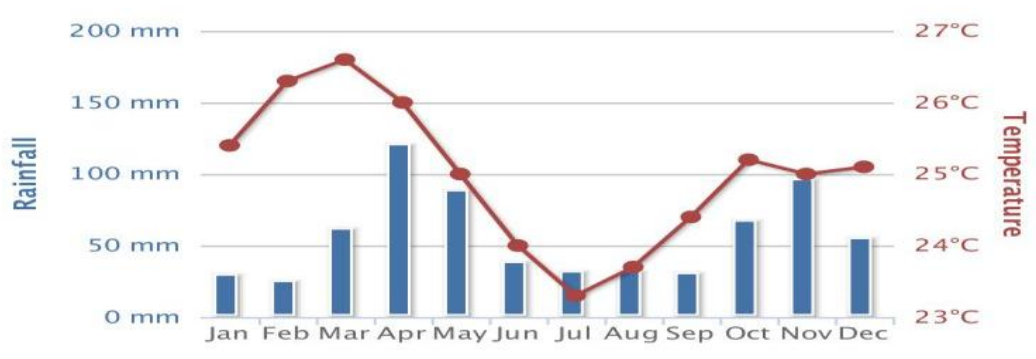

Figure 4: The 1990 - 2012 baseline climate and seasonality trend for LVB, Kenya (Data source: Meteorological department, Kisumu.

In order to understand the attitude of the residents towards climate change and variability, they were asked the question; Who, if any, do you think should be more concerned with climate change issues in the LVB? Their responses were summarized in tables 8 below. Majority of the respondents stated that the national government should take the lead in addressing challenges brought about by climate change in the LVB.

Table 8. Households' view of who should be more concerned with climate change problem

\begin{tabular}{|l|c|c|}
\hline \multirow{2}{*}{ Who, if any, do you think should be more concerned with climate change issues in the LVB? } \\
\cline { 2 - 4 } & \multicolumn{1}{|c|}{ Gwasi Noth male and female) } & $\begin{array}{c}\text { (Both male and } \\
\text { female) }\end{array}$ \\
\hline National government & 251 & 250 \\
\hline County government & 9 & 6 \\
\hline NGOs and CBOs & 0 & 0 \\
\hline Religious organisations & 0 & 0 \\
\hline Households and individuals & 1 & 6 \\
\hline \multicolumn{2}{|c|}{ Total } & \multicolumn{2}{|c|}{} \\
\hline $\mathrm{n}=523 \quad 261$ & 262 \\
\hline
\end{tabular}

Households' practices towards climatic change and variability forcings in the LVB were assessed by asking the participants the question "How does the community cope with severe climatic conditions"? The responses (Table 9) show that $27.2 \%(\mathrm{n}=261)$ and $33.5 \%(\mathrm{n}=262)$ in Gwasi and Nyando respectively, harvest rain water in big tanks and store. In Gwasi $35.3 \%(\mathrm{n}=261)$ and $22.2 \%(\mathrm{n}=262)$ in Nyando respectively use donkeys to carry water and firewood while $34.9 \%(n=261)$ in Gwasi and $43.1 \%(n=262)$ in Nyando use river or Lake water during drought. None of the residents of Gwasi migrate during floods, However, in Nyando11.1\% $(\mathrm{n}=261)$ reported that they migrate during floods. However, $2.7 \%(\mathrm{n}=261)$ in Gwasi stated that they do nothing specific during severe climatic conditions. 
Table 3. Households' coping practices towards severe climatic conditions. (viii).How does the community cope with severe climatic conditions.

\begin{tabular}{|l|l|l|}
\hline Responses & Gwasi & Nyando \\
\hline Harvest rain water in big tanks and store & 71 & 88 \\
\hline Use Donkeys to carry water and firewood & 92 & 32 \\
\hline Use river or Lake water during drought & 91 & 113 \\
\hline Migrate during floods & 0 & 29 \\
\hline Do nothing specific & 7 & 0 \\
\hline Total & 261 & 262 \\
\hline $\mathrm{n}=523$ & \multicolumn{2}{|l}{} \\
\hline
\end{tabular}

Source: Cross sectional survey by author.

Table 10 below shows the types of animals kept in Gwasi area. The table reveals that $99.2 \%$ ( $\mathrm{n}=523$ ) of the study respondents keep at least one local chicken. A bout $88.6 \%$ of the respondents own at least one local goat while $80.8 \%$ of the respondents had at least one cow. Other domestic animals are kept by less than $36 \%$ $(\mathrm{n}=523)$ of the study participants i.e sheep (35.6\%), donkeys (16.8\%) with pigs at $12.3 \%$ and ducks $7.3 \%$.

Table 10. Types of livestock kept by households in Gwasi and Nyando

\begin{tabular}{|l|l|l|l|l|}
\hline $\begin{array}{l}\text { Type of livestock } \\
\text { Kept }\end{array}$ & $\begin{array}{l}\text { No. of households } \\
\text { owning livestock }\end{array}$ & Percentage & $\begin{array}{l}\text { No. of households } \\
\text { without livestock }\end{array}$ & Percentage \\
\hline Local chicken & 259 & $99.2 \%$ & 3 & $1.1 \%$ \\
\hline Goat & 221 & $84.6 \%$ & 40 & $15.3 \%$ \\
\hline Cow & 211 & $80.8 \%$ & 50 & $19.1 \%$ \\
\hline Sheep & 93 & $35.6 \%$ & 168 & $64.3 \%$ \\
\hline Donkeys & 44 & $16.8 \%$ & 217 & $83.1 \%$ \\
\hline Pig & 32 & $12.3 \%$ & 229 & $87.7 \%$ \\
\hline Ducks & 79 & 242 & $92.7 \%$ \\
\hline $\mathrm{n}=261$ & $7.3 \%$ & \multicolumn{2}{|l|}{} \\
\hline
\end{tabular}

\section{CONCLUSION AND RECOMMENDATIONS}

The study assessed the prevailing knowledge, perception and practices of households in the LVB, Kenya and their adaptive capacity. The study revealed that the respondents generally had good knowledge of climate change and variation. There was agreement across the study sites that the climate in the LVB, Kenya has changed overtime. However, the average monthly income of the surveyed households was generally low. The residents in the study sites have various adaptive practices ranging from water conservation to livestock husbandry. The households' heads held the view that the government should take the lead in addressing the challenges brought about by climate change. It is noticeable that the households' CCA capacity is dictated to a large extent by their KAP in addition to the socio-economic factors. It is therefore recommended that any future CCA programmes should be supported both financially and technically in view of the low average monthly household income in the LVB, Kenya. It is also recommended that more surveys be carried out to assess the general impact of CCA on the residents around the LVB, Kenya especially, community livelihood.

\section{REFERENCES}

[1] Elrick-Barr, C. E., B. L. Preston, D. C. Thomsen, and T. F. Smith. Toward a new conceptualization of household adaptive capacity to climate change: applying a risk governance lens. Ecology and Society. 19(4): 2014. 12.

[2] Dulal, H. et al. Capitalising on Assets: vulnerability and adaptation to climate change in Nepal. Washington, DC: World Bank.2010. (www-wds.worldbank.org/external/default/ WDS ContentServer/WDSP/IB /2010/05/25/000333038_ 20100525035359.Accessed 24-1-2017.

[3] Brooks, N. and Adger, N. Assessing and Enhancing Adaptive Capacity: Technical Paper 7. New York: UNDP;2004.(http://ncsp.undp.org/docs/717.pdf).

[4] IPCC. Climate change, adaptation, and vulnerability. Environ. 24: 2014 1-44. http://

[5] Ipcc-wg2.gov /AR5 /images/uploads/IPCC_WG2AR5_SPM_Approved.pdf.Accessed 12- 11-2016

[6] Lindsey Jones, Eva Ludi and Simon Levine. Towards a characterisation of adaptive capacity: a framework for analysing adaptive capacity at the local level. ODI Background Note.2010, London: Overseas Development Institute. 
[7] Swallow BM, Sang JK, Nyabenge M, Bundotich DK, Duraiappah, Yatich TB Trade-off synergies and traps among ecosystem services in the LVB of EA.Env.Sc.and policy. (2009).

[8] Obiero K, Raburu PO Okeyo-Owuor, Raburu Elizabeth. Community perceptions on the impact of the recession of Lake Victoria waters on Nyando wetlands. Scientific Research and Essays Vol.7 (16), (2012).pp.1647-1661

[9] Kenya National Bureau of Statistics (KNBS, 2011). 2009 Kenya Population and Housing Census. Nairobi: KNBS 